\title{
REAKTUALISASI NILAI-NILAI KEBANGSAAN DALAM MASYARAKAT PLURALIS DI KOTA MEDAN
}

Oleh :

\author{
Rosmaida Sinaga
}

\begin{abstract}
ABSTRAK
Kota Medan merupakan salah satu wilayah Indonesia yang didiami berbagai suku, agama, ras dan antargolongan. Keberagaman suku, agama, ras, budaya, dan bahasa di Kota Medan merupakan indikator masyarakat pluralis. Sebagai masyarakat yang pluralis, mempunyai dua sisi yang saling bertolak belakang. Di satu sisi, keragaman tersebut berdampak positif, dan di sisi lain berdampak negative. Keragaman masyarakat Kota Medan dapat berdampak positif, apabila mampu dikelola menjadi modal sosial untuk membangun persepsi bersama dan visi bangsa tanpa mengabaikan keragaman budaya. Di sisi lain keragaman itu juga berdampak negatif karena masyarakat pluralis sangat rawan terhadap munculnya disintegrasi bangsa. Ancaman disintegrasi bangsa dapat dicegah dengan mengaktualkan (menghidupkan) kembali nilai-nilai kebangsaan yang bersumber dari nilai-nilai luhur bangsa. Adapun nilai-nilai luhur bangsa yang mampu menjadi perekat dan pengikat persatuan adalah Pancasila, UUD 45, NKRI dan Bhinneka Tunggal Ika.
\end{abstract}

Kata kunci: masyarakat pluralis, nilai-nilai kebangsaan, Kota Medan 


\section{PENDAhuluan}

Secara Geopolitik, Indonesia merupakan negara lautan (archipelago) yang ditaburi oleh pulau-pulau, yang dikenal dengan istilah Negara Kepulauan. Letak Indonesia yang berada pada posisi titik persilangan antar benua dan antar samudera menyebabkan terjadinya penyerbukan dan silang budaya dari peradaban besar dunia. Indonesia sebagai Negara kepulauan terdiri dari ribuan pulau, beragam suku bangsa, bahasa, budaya, agama, adat istiadat, dan keberagaman lainnya ditinjau dari beberapa aspek. Indonesia menjadi bangsa yang majemuk secara paripurna karena kemajemukan kultural, agama, sosial dan territorial yang mampu menyatu dalam komunitas politik kebangsaan Indonesia.

Sejak awal berdirinya Negara Indonesia, kemajemukan merupakan kekayaan Indonesia yang harus diakui, diterima dan dihormati. Kemajemukan sebagai anugerah harus dipertahankan, dipelihara, dan dikembangkan yang kemudian diwujudkan dalam semboyan Bhinneka Tunggal Ika. Bhinneka Tunggal Ika dipakai sebagai semboyan pemersatu yang merangkul keberagaman bangsa Indonesia.

Salah satu wilayah Indonesia yang dihuni masyarakat prularis adalah Kota Medan. Kota Medan sebagai ibukota Provinsi Sumatera Utara didiami masyarakat yang sangat majemuk. Penduduknya terdiri dari beraneka ragam suku bangsa, agama, budaya dan bahasa. Adapun suku-suku bangsa yang berdiam di Kota Medan adalah Suku Melayu, Batak, Nias, Jawa, Minang, Aceh, Banjar, Arab, Cina, dan India dan lain-lain. Agama yang dianut penduduk Kota Medan juga beraneka ragam yaitu Agama Islam, Protestan, Katolik, Hindu, Budha, Parmalim dan aliran kepercayaan lainnya. Oleh karena itu, masyarakat Kota Medan disebut juga masyarakat yang pluralistik.

Masyarakat pluralis sangat rawan terhadap munculnya disintegrasi bangsa yang disebabkan berbagai faktor baik yang berasal dari dalam maupun luar negeri. Untuk mencegah disintegrasi bangsa diperlukan sebuah prasyarat tertentu untuk tetap mempertahankan persatuan ditengah pluralitas nilai dan kepentingan. Hal inilah yang mendorong pentingnya nilai-nilai kebangsaan sebagai pemersatu diaktualisasikan dalam masyarakat yang pluralistik, sehingga terhindar dari ancaman yang serius 
terhadap persatuan dan kesatuan serta nilai-nilai luhur kehidupan berbangsa. Oleh karena itu, penulis tertarik untuk mengkaji reaktualisasi nilai-nilai kebangsaan dalam masyarakat pluralis di Kota Medan.

\section{II.PEMBAHASAN}

\section{A. Pengertian Reaktualisasi dan Nilai-nilai Kebangsaan}

Kata reaktualisai berasal dari bahasa Inggris actual yang berarti sebenarnya atau sesungguhnya, dan actualize yang berarti mewujudkan dan melaksanakan. Kata tersebut disusun dari kata re dan actualize menjadi reactulization yang berarti menghidupkan kembali atau mewujudkan dan membangun kembali.

Menurut Julianda B. Manalu, nilai adalah konsep umum tentang sesuatu yang dianggap baik, patut, layak, pantas keberadaannya dicita-citakan, diinginkan, dihayati, dan dilaksanakan dalam kehidupan sehari-hari dan menjadi tujuan kehidupan bersama di dalam kelompok masyarakat tersebut, mulai dari unit kesatuan sosial terkecil hingga suku, bangsa dan masyarakat internasional.

Reaktualisasi nilai-nilai kebangsaan berarti mengaktualkan (menghidupkan) kembali nilai-nilai kebangsaan. Dengan kata lain, reaktualisasi nilai-nilai kebangsaan adalah upaya untuk membangun kembali satu karakter bangsa yang berdaulat dan berintegritas tinggi.

Nilai-nilai kebangsaan bersumber dari nilai-nilai budaya yang dimiliki bangsa itu sendiri. Menurut Ernest Renan, nilai kebangsaan adalah suatu asas kerohanian yang timbul dari kemuliaan bersama yang merupakan aspek historis dan aspek solidaritas yang tetap mempergunakan warisan masa lampau. Nilai-nilai kebangsaan Indonesia berakar dari nilai-nilai budaya Indonesia yang dijadikan sebagai pemersatu bangsa dari berbagai ras dan suku bangsa. Nilai-nilai kebangsaan tersebut menjadi tali pengikat untuk menjalin persatuan dan kesatuan dari berbagai suku bangsa menjadi satu bangsa Indonesia. Lebih lanjut Rustam E. Tamburaka (1999: 82) menjelaskan bahwa nilai kebangsaan yaitu bila warga negara bersedia memberikan pengorbanan bagi eksistensi bangsanya, maka bangsa tersebut tetap bersatu dalam kelangsungan hidupnya. 


\section{B. Masyarakat Pluralis Kota Medan dan Dampaknya}

Medan adalah kota multietnis, yang penduduknya terdiri dari orang-orang dengan latar belakang budaya dan agama yang berbeda-beda. Dengan kata lain, masyarakat Kota Medan merupakan masyarakat pluralis. Kemajemukan penduduk Kota Medan dilihat dari keberagaman etnis yang berdiam di wilayah itu. Penduduk Kota Medan menurut golongan etnis terdiri dari penduduk asli yaitu Suku Melayu, Batak Karo, Batak Simalungun, Batak Toba, Batak Dairi/Fakfak, Batak Mandailing, Batak Angkola, dan Nias. Golongan pribumi pendatang adalah suku Jawa, Aceh, Sunda, Bali, Ambon, Minahasa, Banjar Palembang, Riau, Minangkabau dan lain-lain. Sedangkan penduduk asing adalah orang Arab, India, Cina dan bangsa-bangsa lainnya.

Keberagaman etnis yang berdiam di Kota Medan bertalian dengan pembukaan perusahaan perkebunan secara besar-besaran pada masa kolonial Belanda. Pada akhir abad ke-19 dan awal abad ke-20 terdapat dua gelombang migrasi besar ke Medan. Gelombang migrasi pertama berupa kedatangan orang Tionghoa dan Jawa sebagai kuli kontrak perkebunan. Namun, setelah 1880 pemilik perusahaan perkebunan tidak lagi mendatangkan orang Cina sebagai buruh perkebunan. Kebijakan tersebut diambil karena sebagian besar dari buruh Cina lari dari perkebunan dan sebagian lagi sering melakukan kerusuhan. Oleh karena itu, pemilik perusahaan perkebunan lebih memilih untuk mendatangkan orang Jawa sebagai kuli perkebunan. Orang-orang Cina bekas buruh perkebunan didorong oleh pemerintah kolonial Belanda untuk mengembangkan sektor perdagangan. Gelombang migrasi kedua adalah kedatangan orang Minangkabau, Mandailing dan Aceh. Mereka datang ke Medan bukan untuk bekerja sebagai buruh perkebunan, melainkan untuk berdagang, menjadi guru dan ulama.

Keberagaman penduduk Kota Medan dilihat dari agama yang dianut, yaitu agama Islam, Kristen, Katolik, Budha, Hindu, Parmalim dan aliran kepercayaan lainnya. Keberagaman agama di Kota Medan dapat dilihat dari jumlah mesjid, gereja dan vihara yang dibangun pemeluk agama masing-masing.

Keberagaman penduduk Kota Medan juga dapat diketahui dari bahasa yang

digunakan masyarakatnya. Bahasa yang digunakan dalam kehidupan sehari-hari sanat 
beragam yaitu Indonesia, Melayu, Batak, Jawa, Hokkien, Minangkabau, Aceh, Mandailing dan Tamil.

Kemajemukan masyarakat Kota Medan di satu sisi memiliki dampak positif, di sisi yang lain memiliki dampak negatif. Sebagaimana diketahui bahwa masing-masing suku bangsa mempunyai kelebihan yang dapat menutupi kekurangan dari suku lainnya. Keragaman tersebut dapat berdampak positif, apabila mampu dikelola menjadi modal sosial untuk membangun persepsi bersama dan visi bangsa tanpa mengabaikan keragaman budaya. Dengan demikian keberagaman suku bangsa di Kota Medan dapat menjadi modal sosial dalam pembangunan wilayah itu. Menurut Lyda Judson Hanifan dalam Rusidy Syahra (2003: 1) bahwa modal sosial bukanlah modal dalam arti kata biasa seperti harta kekayaan atau uang, tapi lebih mengandung arti kiasan, namun merupakan asset atau modal nyata yang penting dalam hidup bermasyarakat. Modal sosial termasuk kemauan baik, rasa bersahabat, saling simpati, serta hubungan sosial dan kerjasama yang erat antara individu dan keluarga yang membentuk suatu kelompok sosial. Lebih lanjut Bourdieu dalam Rusidy Syahra (2003: 4) mendefenisikan modal sosial sebagai keseluruhan sumber daya baik yang aktual maupun potensial terkait kepemilikan jaringan hubungan kelembagaan yang tetap dengan didasarkan pada saling kenal dan saling mengakui. Dengan menjadi anggota dari suatu kelompok orang memperoleh dukungan dari modal yang dimiliki secara kolektif. Besarnya modal sosial yang dimiliki seorang anggota dari suatu kelompok tergantung pada seberapa jauh kuantitas maupun kualitas jaringan hubungan yang dapat diciptakannya, serta seberapa besar volume modal ekonomi, budaya dan sosial yang dimiliki oleh setiap orang yang ada dalam jaringan hubungannya.

Kemajemukan masyarakat Kota Medan memiliki probabilitas yang tinggi dalam menimbulkan perpecahan. Keberagaman suku, agama, ras dan bahasa mengakibatkan banyak perbedaan dan keragaman karakter. Perbedaan kultur dan keragaman karakter tersebut dapat menimbulkan sentimen-sentimen kelompok yang merupakan ancaman persatuan dan kesatuan bangsa. Hal ini sejalan dengan pendapat Kahin (1995: 77) 
bahwa sifat plural masyarakat Indonesia, terutama kelompok sosial ekonomi dan kelompok etnis yang sejalan, sangat membatasi pertumbuhan nasionalisme Indonesia. Munculnya ancaman yang serius terhadap disintegrasi bangsa disebabkan berbagai faktor baik yang berasal dari dalam maupun luar negeri. Faktor yang berasal dari dalam negeri antara lain:

1) Lemahnya penghayatan dan pengamalan agama dan munculnya pemahaman terhadap ajaran agama yang keliru dan sempit, serta tidak harmonisnya pola interaksi antarumat beragama

2) Sistem sentralisasi pemerintahan dan pengabaian terhadap pembangunan dan kepentingan daerah serta timbulnya fanatisme kedaerahan

3) Tidak berkembangnya pemahaman dan penghargaan atas kebhinnekaan dan kemajemukan dalam kehidupan berbangsa.

4) Terjadinya ketidakadilan ekonomi dan munculnya perilaku ekonomi yang bertentangan dengan moralitas dan etika

5) Kurangnya keteladanan dalam sikap dan perilaku sebagian pemimpin dan tokoh bangsa

6) Tidak berjalannya penegakan hukum secara optimal, dan lemahnya kontrol sosial untuk mengendalikan perilaku yang menyimpang dari etika yang masih berlaku dalam masyarakat

7) Adanya keterbatasan kemampuan budaya lokal, daerah dan nasional dalam merespon pengaruh negatif dari budaya luar

8) Meningkatnya prostitusi, media pornografi, perjudian, pemakaian, peredaran dan penyeludupan obat-obat terlarang.

9) Pemahaman dan implementasi otonomi daerah yang tidak sesuai dengan semangat konstitusi.

Sedangkan faktor-faktor yang berasal dari luar negeri antara lain:

1) Pengaruh globalisasi kehidupan yang semakin meluas dengan persaingan antarbangsa yang semakin tajam 
2) Makin kuatnya intensitas intervensi kekuatan global dalam perumusan kebijakan nasional (Pimpinan MPR dan Tim Kerja Sosialisasi MPR Periode 2009-2014, 2012: 14-15).

Faktor-faktor penghambat tersebut merupakan ancaman terhadap persatuan dan kesatuan masyarakat yang majemuk. Oleh sebab itu, penting dilaksanakan reaktualisasi nilai-nilai kebangsaan dalam masyarakat yang pluralis.

\section{Nilai-Nilai Kebangsaan Sebagai Perekat dan Pengikat Kerukunan Bangsa}

Sejak awal berdirinya Negara Kesatuan Republik Indonesia (NKRI), para pendiri negara menyadari bahwa keberadaan masyarakat yang majemuk merupakan kekayaan bangsa Indonesia yang harus diakui, diterima dan dihormati, yang diwujudkan dalam semboyan Bhinneka Tunggal Ika. Namun, kenyataan dalam sejarah perjalanan bangsa, sebagian masyarakat Indonesia tidak mampu mengelola kemajemukan dan tidak siap menerima kemajemukan tersebut. Akibatnya terjadi berbagai gejolak yang membahayakan persatuan dan kesatuan. Hal tersebut berpotensi melahirkan konflik baik konflik vertikal antara pusat dan daerah maupun konflik horizontal antar berbagai unsur masyarakat, pertentangan ideologi, agama, kemiskinan struktural, kesenjangan sosial dan lain lain (Pimpinan MPR dan Tim Kerja Sosialisasi MPR Periode 20092014, 2012: X-xi).

Negara Indonesia yang mempunyai heterogenitas yang kompleks dengan potensi disintegrasi yang tinggi, seyogiyanya setiap langkah dan kebijakannya diarahkan untuk memperkuat persatuan dan kesatuan serta memperkokoh komitmen kebangsaan dengan memandang bahwa keanekaragaman ras, suku, agama dan bahasa daerah merupakan khasanah budaya yang justru dapat menjadi unsur pemersatu bangsa. Komitmen kebangsaan pada hakikatnya adalah usaha meningkatkan nasionalisme dan rasa kebangsaan sebagai suku bangsa yang bersatu dan berdaulat dalam wilayah NKRI (Pimpinan MPR dan Tim Kerja Sosialisasi MPR Periode 2009-2014, 2012: xi). Oleh karena itu diperlukan adanya semangat dan ketulusan segenap komponen bangsa untuk menerapkan nilai-nilai luhur tersebut sebagai kontrol dan koreksi dalam 
penyelenggaraan Negara, sehingga pelaksanaan kehidupan berbangsa dan bernegara tetap dalam koridor mencapai tujuan Negara.

Nilai-nilai luhur bangsa terdapat dalam empat konsepsi Empat Pilar Kehidupan Berbangsa dan Bernegara, yaitu Pancasila, UUD RI Tahun 1945, NKRI, dan Bhinneka Tunggal Ika. Keempat pilar tersebut merupakan prinsip-prinsip moral keindonesiaan yang memandu tercapainya perikehidupan bangsa yang merdeka, bersatu, berdaulat, adil dan makmur.

Menurut Julianda B. Manalu bahwa nilai-nilai kebangsaan terdapat dalam empat pilar kehidupan berbangsa dan bernegara. Selanjutnya akan diuraikan nilai-nilai kebangsaan yang terkandung dalam masing-masing pilar tersebut. Pancasila sebagai salah satu pilar kehidupan berbangsa dan bernegara melahirkan nilai-nilai kebangsaan Indonesia sebagai berikut:

1) Nilai religiositas, yakni nilai-nilai spiritual yang tinggi yang harus dimiliki manusia Indonesia yang berdasarkan agama dan keyakinan yang dipeluknya dan memiliki toleransi yang tinggi terhadap pemeluk agama dan keyakinan lain yang tumbuh dan diakui di Indonesia.

2) Nilai kekeluargaan, mengandung nilai kebersamaan dan senasib dan sepenanggungan dengan sesama warga Negara tanpa membedakan asal-usul, agama, keyakinan, latar belakang sosial dan politik seseorang.

3) Nilai keselarasan, memiliki kemampuan untuk beradaptasi dan berkeinginan untuk memahami dan menerima budaya dan kearifan lokal sebagai perwujudan dari nilai-nilai kemajemukan Indonesia.

4) Nilai kerakyatan, memiliki sifat dan komitmen untuk berpihak pada kepentingan rakyat banyak dalam merencanakan, merumuskan dan menjalankan kebijakan publik, sebagai perwujudan dari prinsip kedaulatan rakyat dan bangsa yang berdaulat.

5) Nilai keadilan, memiliki kemampuan untuk menegakkan dan berbuat adil kepada sesama manusia serta mewujudkan keadilan bagi seluruh rakyat Indonesia.

Nilai-nilai kebangsaan yang bersumber dari NKRI sebagai berikut: 
1) Nilai kesatuan wilayah, sebagai konsekuensi dan realitas geografis Indonesia sebagai Negara kepulauan dengan perairan sebagai pemersatu ribuan pulau, bukan sebagai pemisah.

2) Nilai persatuan bangsa, sebagai realisasi dari realitas Indonesia sebagai bangsa yang majemuk, agama, suku, ras, budaya, politik dan sebagainya.

3) Nilai kemandirian, membangun Negara dan bangsa di atas prinsip kemandirian dengan mengoptimalkan kemampuan sumber daya manusia, alam, dan budaya yang dimiliki Indonesia serta diprioritaskan seluas-luasnya bagi kesejahteraan dan kejayaan bangsa Indonesia.

Nilai-nilai kebangsaan yang bersumber dari semboyan Bhinneka Tunggal Ika sebagai berikut:

1) Nilai toleransi, sikap mau memahami dan menerima kehadiran orang lain yang berbeda (keyakinan, suku, bahasa, politik dan lain-lain) untuk hidup berdampingan secara damai.

2) Nilai keadilan, yaitu sikap seimbang antara mendapatkan hak dan menjalankan kewajiban sebagai warga Negara.

3) Nilai gotong royong, sebagai sikap dan tindakan untuk bekerja sama dengan orang maupun kelompok warga bangsa yang lain dalam urusan-urusan yang terkait dengan kepentingan bersama, kemasyarakatan dan Negara.

Nilai-nilai kebangsaan yang bersumber dari UUD 1945 sebagai berikut:

1) Nilai demokrasi, yang mengandung makna bahwa kedaulatan berada di tangan rakyat, dan setiap warga Negara memiliki kebebasan berserikat dan mengemukakan pendapat secara bertanggung jawab.

2) Nilai kesamaan derajat, setiap warga Negara memiliki kedudukan yang sama di hadapan hukum

3) Nilai ketaatan hukum, setiap warga Negara tanpa pandang bulu harus taat hukum dan peraturan yang berlaku.

Nilai-nilai kebangsaan yang terkandung dalam keempat pilar kehidupan berbagsa dan bernegara harus kita jaga, pahami, hayati, dan laksanakan dalam pranata 
kehidupan sehari-hari, di mana Pancasila yang menjadi sumber nilai menjadi ideologi, UUD 45 sebagai aturan semestinya ditaati, NKRI adalah harga mati, serta Bhinneka Tunggal Ika adalah perekat semua rakyat. Dengan menjaga, memahami, menghayati dan melaksanakan nilai-nilai kebangsaan, bangsa Indonesia akan mampu mewujudkan tujuan yang dicita-citakan.

\section{Pentingnya Reaktualisasi Nilai-nilai Kebangsaan pada Masyarakat Pluralis di Kota Medan}

Reaktualisasi nilai-nilai kebangsaan merupakan suatu hal yang mutlak dilakukan dalam kehidupan berbangsa dan bernegara di era globalisasi. Masyarakat Kota Medan sebagai masyarakat yang pluralistik, tengah berada di pusaran arus globalisasi yang akan mempengaruhi pola pikir masyarakatnya dalam memandang kehidupan berbangsa dan bernegara. Dalam era globalisasi melekat proses transformasi sistem nilai yang tidak dapat dibendung. Dewasa ini ada indikasi bangsa Indonesia tengah mengalami krisis kebangsaan. Hal ini terbukti dari munculnya kelompok-kelompok eklusifisme berdasarkan pada sentimen primordial, terutama setelah diberlakukannya otonomi daerah. Misalnya, untuk memenangkan seorang calon dalam Pilkada, para pengusung calon tersebut memunculkan segregasi agama, suku dan ras. Semestinya para elit politik bertugas untuk mensosialisasikan visi dan misinya dalam meningkatkan kesejahteraan masyarakat. Selanjutnya masyarakatlah yang menilai visi dan misi calon kepala daerahnya tanpa dipengaruhi sentiment primordial. Sebelum Negara ini terbentuk, para pejuang nasional Indonesia telah berupaya membangkitkan nasionalisme. Budi Utomo pada 20 Mei 1908 telah menggagas kebangkitan nasionalisme. Kebangkitan nasionalisme diperingati bangsa Indonesia setiap tahunnya pada tanggal 20 Mei. Peringatan kebangkitan nasionalisme hendaknya jangan hanya menjadi seremonial belaka. Akan tetapi, upacara peringatan kebangkitan nasionalisme seyogiyanya mampu menanamkan semangat nasionalisme dalam sanubari setiap insan Indonesia. 
Dalam perspektif historis, Sumpah Pemuda pada 28 Oktober 1928 adalah suatu penyatuan perpsepsi bangsa - setidaknya melalui para pemudanya, yang berasal dari berbagai daerah Kepulauan Indonesia untuk melawan imperialisme dan kolonialisme Belanda. Substansi Sumpah Pemuda sesungguhnya adalah nilai persatuan yang hendak disebarluaskan ke daerah-daerah yang kemudian menjadi wilayah NKRI. Secara prinsip, semangat persatuan tidak berarti mengabaikan masyarakat majemuk dengan keragaman budayanya, misalnya: sejarah, bahasa, hukum adat. Keindonesiaan berdiri tegak dalam kerangka masyarakat yang majemuk dengan keragaman budayanya (Susanto Zuhdi, 2014: 305-306). Hal ini jelas menunjukkan kesadaran untuk menjadi satu bangsa, bangsa Indonesia tanpa membedakan suku, ras, budaya dan agama. Titik kulminasi dari perjuangan untuk membentuk suatu bangsa adalah Proklamasi 17 Agustus 1945. Mengapa dewasa ini bangsa Indonesia lupa bahwa bangsa Indonesia itu dibentuk dari keberagaman suku bangsa, ras agama, budaya, bahasa dan adat istiadat? Jawabannya adalah karena nilai-nilai kebangsaan telah tergerus dari sanubari bangsa Indonesia.

Tergerusnya nilai-nilai kebangsaan merupakan salah satu pengaruh negatif dari era globalisasi. Dalam era globalisasi yang ditunjang perkembangan ilmu pengetahuan dan teknologi yang melejit menyebabkan informasi dunia tanpa batas. Imformasi tersebut dengan mudah diakses di media cetak dan elektronik. Teknologi internet merupakan teknologi yang memberikan informasi tanpa batas dan dapat diakses oleh siapa saja. Apalagi bagi anak muda, internet merupakan menu santapan sehari-hari bagi mereka. Jika internet digunakan sebagaimana mestinya tentu akan diperoleh manfaat yang berguna. Namun, kenyataannya banyak pelajar dan mahasiswa yang tidak menggunakan internet sebagaimana mestinya, misalnya membuka situs-situs porno. Selain internet, handphone merupakan pegangan wajib bagi anak-anak muda. Penggunaan handphone di kalangan anak-anak muda memiliki andil yang cukup besar dalam mendegradasi rasa sosial terhadap masyarakat. Rasa sosial terhadap masyarakat menjadi sirna karena mereka lebih memilih sibuk menggunakan handphonenya. 
Tayangan televisi yang mengedepankan budaya-budaya asing yang berpandangan liberalisme, individualisme, serba modern, vulgaritas, dan kurang mengangkat budaya lokal akan mempengaruhi nilai-nilai kebangsaan Indonesia. Informasi televisi berdampak pada bergesernya nilai-nilai kebangsaan yang mengarah pada krisis nasionalisme. Dalam kalangan generasi muda ada indikasi yang cenderung meniru budaya Barat yang oleh masyarakat dunia dianggap sebagai kiblat dan mengabaikan budaya bangsa sendiri serta kurang peduli terhadap masyarakat. Dengan demikian, dampak negatif globalisasi antara lain: pola hidup konsumtif, sikap individualistik, dan gayahidup kebarat-baratan serta kesenjangan sosial.

Perkembangan teknologi informasi dan komunikasi memiliki dua sisi yang saling tolak belakang. Di satu sisi, memberikan dampak positif yang dapat membantu dan memajukan kehidupan bangsa. Di sisi lain, memberikan dampak negative yang justru dapat merusak kehidupan bermasyarakat, berbangsa dan bernegara. Salah satu contoh dampak negative dari perkembangan teknologi informasi dan komunikasi adalah tindakan penggunaan kecanggihan teknologi informasi dan komunikasi untuk hal yang bersifat negative yaitu penyalahgunaan media sosial. Penyalahgunaan media sosial dalam kalangan generasi muda turut pula memecah belah persatuan dan kesatuan bangsa. Salah satu contoh penyalahgunaan media sosial adalah penggunaan media sosial untuk menyebarkan konten ujaran kebencian dan hoaks berbau suku, agama, ras dan antargolongan. Padahal Negara Indonesia adalah Negara yang terdiri dari berbagai suku, agama, ras dan antargolongan.

Saracen merupakan istilah untuk menyebut penebar konten ujaran kebencian (hate speech) dan hoaks berbau suku, agama, ras dan antargolongan untuk menyerang pihak-pihak tertentu. Terbongkarnya jaringan Saracen yang diduga menyebarkan konten SARA melalui teknologi informasi dan komunikasi merupakan salah satu ancaman siber yang serius. Modus kejahatan yang dilakukan kelompok-kelompok penebar kebencian sangat berbahaya dalam masyarakat yang pluralistic. Penyebaran ujaran kebencian yang berbau SARA berpontensi destruktif dan berimplikasi buruk bagi persatuan dan kesatuan bangsa Indonesia karena punya kans memantik api konflik 
horizontal. Konflik horizontal dapat dicegah dengan menumbuhkan kesadaran dalam diri setiap insan Indonesia untuk tidak menebarkan ujaran kebencian yang berbau SARA. Di pihak lain, para penegak hukum harus mampu menindak tegas dan menjatuhkan hukuman yang berat bagi para pelaku penebar kebencian sebagai efek jera (down effect).

Sementara itu, pemerintah dan masyarakat Indonesia berkewajiban untuk menghidupkan kembali nilai-nilai kebangsaan untuk membangun satu bangsa yang dinamakan bangsa Indonesia. Nilai-nilai kebangsaan bersumber dari dan mengakar dalam budaya bangsa Indonesia yang dijadikan tali pengikat yang menjalin persatuan berbagai suku bangsa menjadi satu bangsa, bangsa Indonesia. Rasa kebangsaan pada hakekatnya merupakan persatuan dan kesatuan secara alamiah karena adanya kebersamaan sosial yang tumbuh melalui sejarah dan aspirasi perjuangan masa lalu serta kebersamaan dalam menghadapi tantangan sejarah masa kini. Hal inilah yang mendorong pentingnya reaktualisasi nilai-nilai kebangsaan dalam diri setiap insan Indonesia. Reaktualisasi nilai-nilai kebangsaan penting agar setiap insan Indonesia mengerti dan mendalami nilai-nilai kebangsaan yang telah disepakati bersama dalam Negara Indonesia dan menerapkannya dalam kehidupan bermasyarakat, berbangsa dan bernegara. Reaktualisasi nilai-nilai kebangsaan bermuara pada semakin kokohnya eksistensi bangsa dan Negara Indonesia.

Reaktualisasi nilai-nilai kebangsaan sangat dibutuhkan dalam masyarakat yang pluralistik. Masyarakat Kota Medan sebagai masyarakat yang pluralis seyogiyanya menyadari pentingnya mencegah ujaran kebencian yang berbau SARA dan mengaktualisaikan kembali nilai-nilai kebangsaan dalam kehidupan bermasyarakat, berbangsa dan bernegara.

\section{PENUTUP}

Masyarakat Kota Medan merupakan masyarakat yang pluralistik. Di satu sisi keberagaman etnisitas dengan kebudayaannya dapat dikelola menjadi modal sosial dalam pembangunan. Di sisi lain, keragaman etnisitas dapat juga menjadi ancaman 
terhadap disintegrasi bangsa. Ancaman disintegrasi bangsa dapat dicegah dengan mengaktualkan (menghidupkan) kembali nilai-nilai kebangsaan yang bersumber dari nilai-nilai luhur bangsa. Adapun nilai-nilai luhur bangsa yang mampu menjadi perekat dan pengikat persatuan adalah Pancasila, UUD 45, NKRI dan Bhinneka Tunggal Ika.

\section{DAFTAR BACAAN}

Kahin, George Mc Turnan. (1995). Refleksi Pergumulan Lahirnya Republik: Nasionalisme dan Revolusi di Indonesia. Jakarta: Sinar Harapan.

Manalu, Julianda, B.(TT). Pemantapan Nilai-Nilai Kebangsaan Yang Bersumber Dari NKRI Untuk Meningkatkan Kualitas Kehidupan Bermasyarakat, Berbangsa dan Bernegara.

Pimpinan MPR dan Tim Kerja Sosialisasi MPR Periode 2009-2014.(2012). Empat Pilar Kehidupan Berbangsa dan Bernegara. Jakarta: Sekretaris Jenderal MPR RI.

Rusidy Syahra. (2003). Modal Sosial: Konsep dan Aplikasi. Jurnal Masyarakat dan Budaya, Volume 5 No. 1.

Susanto Zuhdi. (2014). Nasionalisme, Laut, dan Sejarah. Depok: Komunitas Bambu.

Tamburaka, Rustam E. (1999). Pengantar Ilmu Sejarah, Teori Filsafat Sejarah. Jakarta: Rineka Cipta.

Sekilas Teori Kebangsaan Ernest Renan. https://narsulin .wordpress.com/ diakses 1 Agustus 2017. 